\title{
Control over organic carbon of soil in a context of food safety and climate fluctuation
}

\author{
S. Baliuk, \\ Doctor of Agricultural Sciences, Prof., Academician of NAAS, \\ V. Medvedev, \\ Doctor of Biological Sciences, Prof., Academician of NAAS, \\ A. Kucher, \\ PhD of Pedagogical Sciences, Postdoctoral Fellow, \\ Corresponding Member of AESU, \\ V. Solovey, \\ PhD of Agricaltural Sciences, Senior Researcher, \\ A. Levin, \\ Deputy GSP Focal Point of Ukraine \\ National Scientific Center «Institute for Soil Science and Agrochemistry Research named after \\ O.N. Sokolovsky» (NSC ISSAR), \\ Yu. Kolmaz, \\ PhD of Agricaltural Sciences, \\ Ministry of Ecology and Natural Resources of Ukraine, \\ UNCCD Focal Point of Ukraine
}

The purpose. To overview findings of investigation in the role of Ukrainian soils and control over edapic organic carbon in a context of global food safety and stable agrarian production at climate fluctuations. Methods. Theoretical generalization and comparison, abstract-and-logic, monographic, expert, calculationand-analytical. Results. The leading part of Ukraine in formation of global food safety is shown. The tentative estimation of contribution of soils of Ukraine in global problem of deposition of carbon is carried out. Scales of losses of organic carbon because of irrational use of lands are analyzed. Directions of control over procreation of organic carbon in black earth of Ukraine for support/increase of its stores and maintenance of neutral degradation of lands are considered. Offers in plans of action for augmentation of potential of control over the procreation of organic carbon in chernozem soils of Ukraine are stated. Conclusions. At control over organic carbon of soils of Ukraine it is necessary to be guided by increase of potential of cultivated lands on deposition of carbon and reduction of greenhouse effect. Rational use of lands and prevention of degradation of soils can soften consequences of climate fluctuation and raise the level of food safety not only in Ukraine, but all over the world. Sequestration of carbon in soils can raise stability of agrarian production in conditions of climate fluctuation.

Key words: edaphic organic carbon, humus, food safety, neutral degradation of lands, climate fluctuations.

Formulation of the problem. Actuality and scientific and practical significance of the problem of the management of soil organic carbon (carbon contained in the soil organic matter) is due to the fact that it is crucial for soil health, fertility and ecosystem services, including food production - thereby providing essential for sustainable development of its conservation and restoration.

Even as a result of climate change that has a negative impact on agriculture, farmers should produce $60 \%$ more food by 2050 , as it is predicted that the population of the Earth will be increased to 9 billion people. To meet these needs, the soil should be as productive as possible. Soils with high carbon content are likely to be more productive and able to filter and clean water better. 
Water contained in the soil is a source of moisture for the production of $90 \%$ of world agricultural production and accounts for about $65 \%$ of fresh water of the planet. Ground organic carbon plays a major role in climate change, posing both a threat and an opportunity to help achieve the objectives of the Paris Agreement.

Worldwide, carbon stocks in the first meter of soil are estimated at 1417 gigatonne (GT) - almost twice as much as in our atmosphere and ten times as much as the annual amount of anthropogenic emissions. At a greater depth, the soil contains three times more carbon than is present in the atmosphere [1].

These data were made public at the Global Symposium on Soil Organic Carbon, held March 21-23, 2017, at the headquarters of the Food and Agriculture Organization of the United Nations (FAO) in Italy (Rome). The largest event of this level was attended by nearly 500 delegates from 111 countries, including representatives from UNCCD, IPBES, FAO and many scientific and educational institutions from around the world. Ukraine at this event was represented by scientists of the NSC "Institute for Soil Science and Agrochemistry named after O. N. Sokolovsky" (hereinafter referred to as the NSC ISSAR). This article proposes the materials, the key provisions of which were presented at the specified symposium.

Ground organic carbon is sensitive to soil management; irrational use of land is the reason why soils lose organic matter / carbon and emissions of greenhouse gases are occurring.

Due to the degradation of one third of the Earth's soil total emissions to the atmosphere have already been thrown up to $78 \mathrm{Gt}$. Deforestation is responsible for about $25 \%$ of soil organic carbon losses. According to K. Lorenz, R. Lal, subterranean horizons of soil (at a depth of more than 20-30 cm from a surface with a predominantly low carbon content) have a huge potential for sequestration of carbon, as they can store up to 760-1520 Gt of additional carbon [1]

All this requires the study of the role of Ukrainian soils and the management of soil organic carbon as a main factor for sustainability of global food security and agrarian production to climate change.

Analysis of recent research and publications. Scientific and applied aspects of soil organic carbon management are actively investigated by foreign scientists, among which, first of all, it is worth mentioning $R$. Lal. In one of the newest publications, R. Lal, together with co-authors, argue that in the global dimension, the total reserves of organic carbon in soils (taking into account not only the meter but also the deeper layer) can reach values that are five times larger than in the atmosphere.

At the same time, emissions from land-use change account for up to $20 \%$ of atmospheric $\mathrm{CO}_{2}$ due to the loss of biomass and soil organic carbon. Despite this, lately, since the Paris climate summit, attention has been paid to the potential for carbon sequestration through the French initiative "4 pour 1000".

Scientists P. Zdruli, R. Lal, M. Cherlet, S. Kapur argue that the management of soil organic carbon can increase plant productivity, in particular by increasing water use efficiency, optimizing nutrient cycles and supplying them for crop production, increasing vegetation cover and Increasing food security [2].

In the outcome document of the Global Symposium on Soil Organic Carbon, recently published by FAO, an international team of scientists has formulated key recommendations for the management of soil organic carbon in the context of climate change, sustainable development and neutral land degradation [3]. In Ukraine, these issues are investigated by scientists of the NSC ISSAR, in particular, S.A. Baliuk, V.V. Medvedev, A.V. Kucher [4; 5] et al.

The purpose of the article is to highlight the results of the study of the Ukrainian soils role and soil organic carbon management in the context of global food security and the sustainability of agrarian production to climate change.

Research results. General information on land resources and soil cover of Ukraine. The total area of Ukraine as of 01.01 .2016 was $60.35 \mathrm{mln}$.ha, which is equal to $0.4 \%$ of Earth's land area and, accordingly, $6.0 \%$ of the European subcontinent. Land Fund of Ukraine is divided as follows [1]: agricultural lands $-42.74 \mathrm{mln}$.ha or $70,8 \%$ (arable lands -32.53 or $53.9 \%$; hayfields and pastures -7.86 or $13.0 \%$; fallow lands - 0.25 ; gardens - 0.89 or $1.5 \%$; f forest lands - 10.62 or $17,6 \%$; wetlands -0.98 or $1,6 \%$; builtup lands $-2.54 \mathrm{mln}$.ha or $4.2 \%$; other land $-3.46 \mathrm{mln}$.ha or $5.8 \%$ [6, p. 134].

Soil cover of Ukraine is very diverse and has up to 1000 kinds of soil (Fig.1). On 2/3 it consists of chernozems soils (about $25.3 \mathrm{ml}$.ha). At the same time chernozems ordinary cover an area of $10.5 \mathrm{mln}$.ha, 
typical - 5.8, southern - 3.6, podzolized - 3.4 and chernozem-meadow soils - $2.0 \mathrm{mln}$.ha. Also, significant areas are occupied by fertile gray forest soils ( $4.3 \mathrm{mln}$.ha), the sod-podzolic soils (up to $3.9 \mathrm{mln}$.ha), chestnut soils (1.4 mln.ha), brown soils (1.1 mln.ha) and meadow-marsh soils (about $1 \mathrm{mln}$.ha).

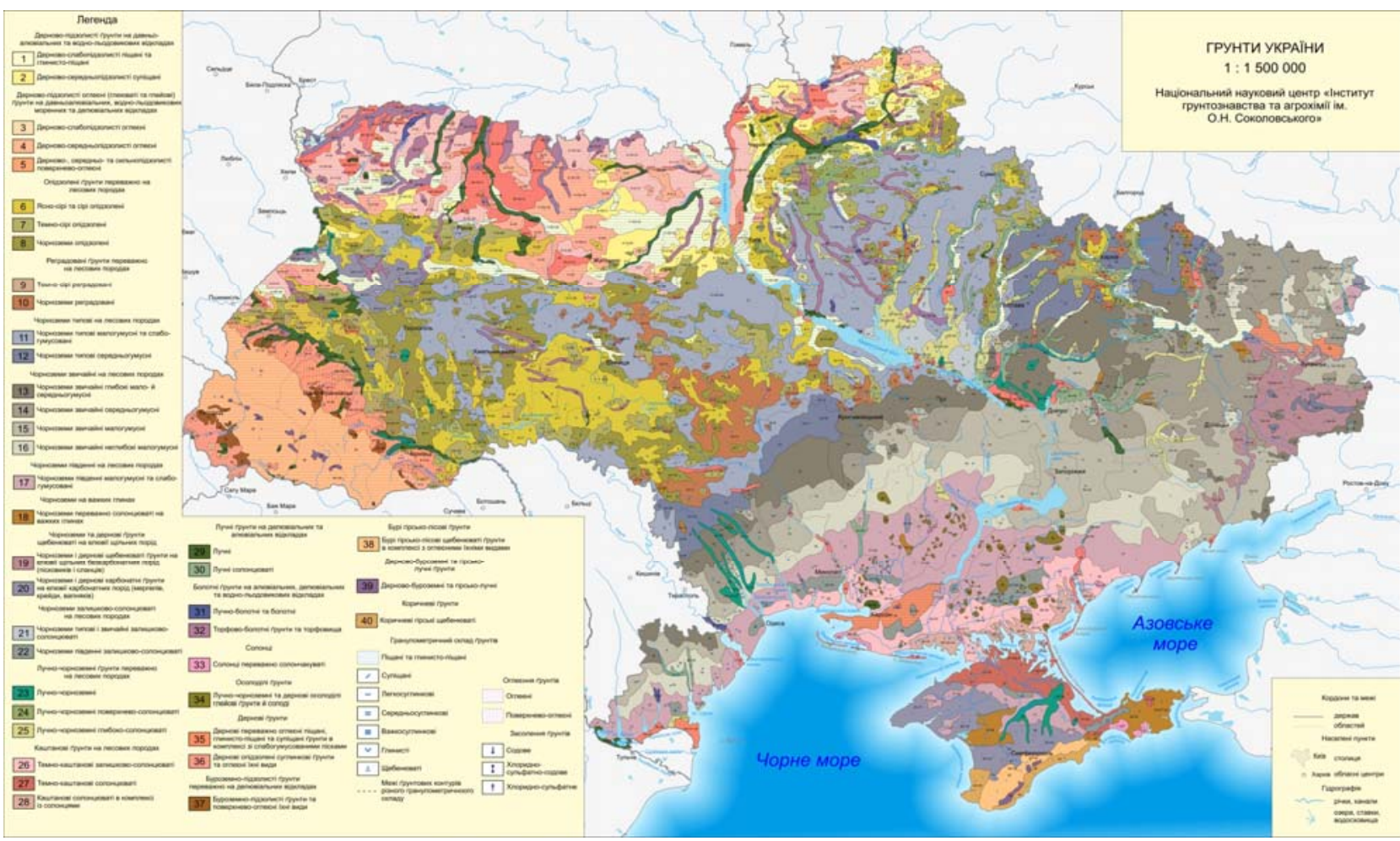

Fig.1: Soil map of Ukraine 1:1 500000 (NSC ISSAR, 2016)

Contribution of Ukrainian soils in the global food security. Due to the high potential of soil resources, Ukraine, together with other leading countries of the world, should be involved in solving global problems of preventing growing food shortages and real risks of the global food crisis.

Potential opportunities for full food supply of humanity are still quite powerful. This is evidenced by a comparative analysis of crop yield and production of basic crop production in Ukraine and in the leading countries of the world per one person [7, p. 15]. Recently, there has been a positive trend towards higher yields.

So, in 2016 Ukraine harvested a record yield of grain and sugar beet. Thus, production of grain and leguminous crops is almost 66 mln.t (which is $9.9 \%$ more than in 2015) at average yield is $4.61 \mathrm{t} / \mathrm{ha}$ (more by $5.0 \mathrm{c} /$ ha than in 2015), gross harvest of sugar beet amounted to $13.9 \mathrm{mln} . t$, which is $35.6 \%$ higher than the previous year, with a yield of $481.5 \mathrm{c} /$ ha (more by $45.7 \mathrm{c} /$ ha than in 2015) (Table 1).

In recent years Ukraine is confidently among ten largest world producers of major products in agrofood sector, both in terms of gross production and the volume of exports. Thus, in 2014 on the production of sunflower and sunflower oil Ukraine held the 1st place in the world, barley - 3rd; nuts - 4th, maize and honey - on 5th; soy - on 8th and wheat - 9th place. On export of sunflower oil Ukraine occupied 1st place; grain and nuts - 2nd; maize and rapeseed - 3rd; barley - 4th; wheat - 6th place in the world. In 2015/2016 marketing year, according to the Ministry of Agrarian Policy and Food, Ukraine exported $39.4 \mathrm{mln}$.t of grain.

1. Gross harvest and yield of agricultural crops in all categories of farms of Ukraine, 2016 ${ }^{1}$

\begin{tabular}{|l|l|l|}
\hline Culture & $\begin{array}{l}\text { Gross harvest, } \\
\text { ths. Tons }\end{array}$ & $\begin{array}{l}\text { Yield, } \\
\text { c / ha }\end{array}$ \\
\hline Cereals and legumes & 66088.0 & 46.1 \\
\hline Soy & 4277.0 & 23.0 \\
\hline Rapeseed and colza & 1153.9 & 25.7 \\
\hline Sunflower & 13626.9 & 22.4 \\
\hline
\end{tabular}




\begin{tabular}{|l|l|l|}
\hline Flax-fiber & 1.3 & 9.0 \\
\hline Sugar beet & 14011.3 & 481.5 \\
\hline Potatoes & 21750.3 & 165.8 \\
\hline Vegetable crops & 9414.5 & 210.5 \\
\hline Fruit and berry crops & 2007.3 & 101.9 \\
\hline Grape & 377.8 & 88.4 \\
\hline
\end{tabular}

${ }^{1}$ Information is provided (according to the State Statistics Service of Ukraine) without taking into account the temporarily occupied territory of the Autonomous Republic of Crimea, the city of Sevastopol and parts of the zone of the antiterrorist operation.

Describing Ukraine's role in the formation of global food security, we note that in recent years it is confidently included in the top ten largest producers of the main types of products in the agro-food sector in the world, both in terms of gross volume of production and exports (in 2014, according to the Reference book "Agribusiness of Ukraine"): first place - for the production of sunflower, sunflower oil and its export; second place - on the export of grain and nuts; third place - by export of corn and rape and for the production of barley; fourth place - for the production of nuts and the export of barley; fifth place - for the production of corn and honey; sixth place - on the export of wheat; eighth place - for the production of soy and export of chicken; ninth place - for the production of wheat.

Presented data show that Ukraine plays a strategic role in the global food market and in ensuring of the global food security. Ukraine declares itself as a full-fledged player, who ranks 2-3 in the world in a number of positions, which can not be ignored. In 2015, Ukraine became one of the top 10 exporters of agricultural products to the European Union, having eighth place in the ranking of the most developed agrarian countries [8].

Preliminary assessment of Ukrainian soils contribution into global carbon sequestration. Soils of Ukraine are characterized, in general, by average (2-3\%) and high (3-4\%) humus content in arable layer (map on Fig.2).

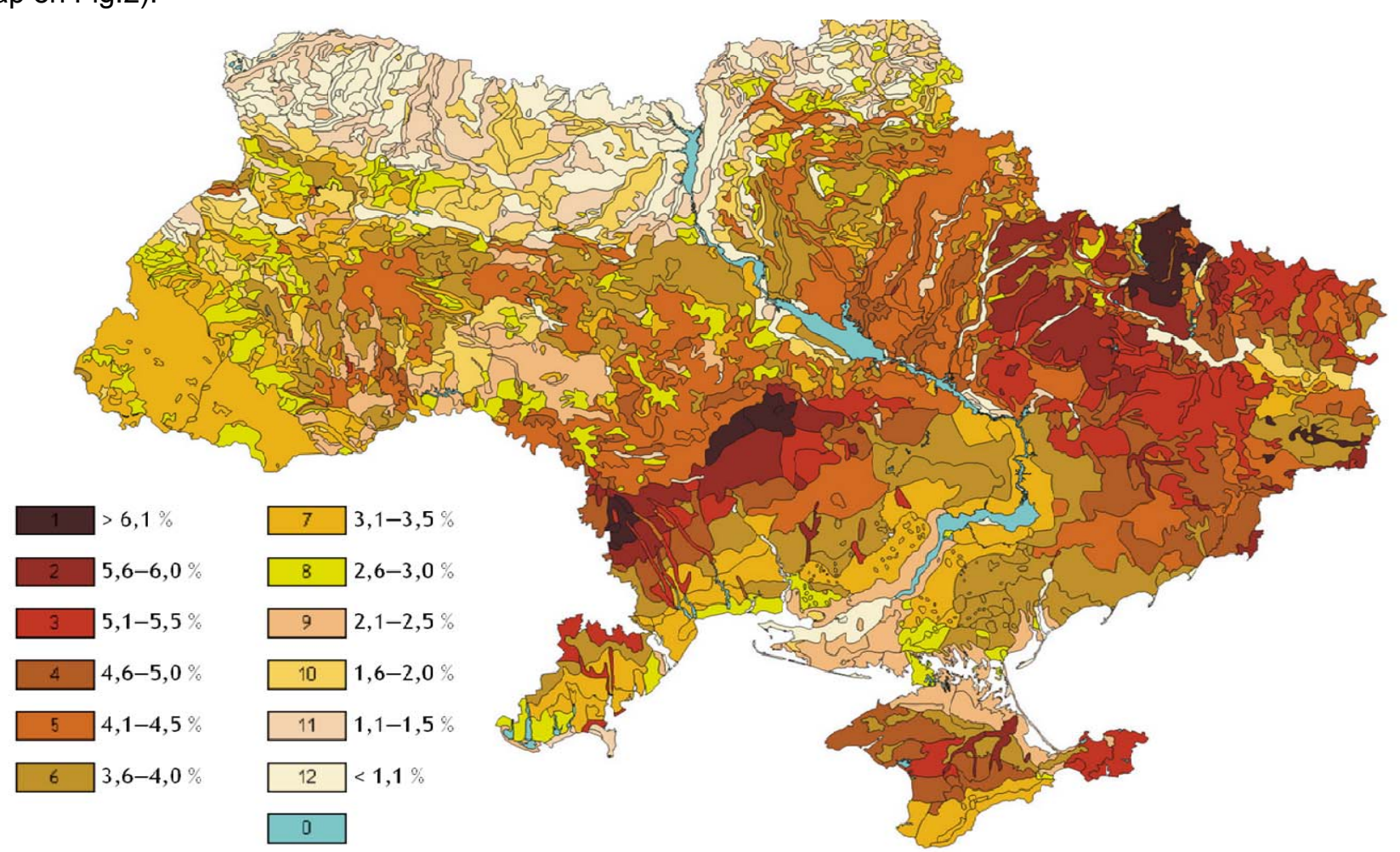

Fig. 2. Map of the humus content in arable layer of Ukrainian soils (NSC ISSAR, 2007)

Soil area with this content is 16.4 mil.ha, or about half of the arable land. Soils with low (1-2\%) and very low $(<1 \%)$ content of humus are distributed in the Polissya area, where soils of sandy and sandy 
granulometric soils are concentrated. The depth of the profiles of Ukrainian soils varies in very wide limits and for chernozem soils, depending on geographical, climatic and other factors, ranges from 50 to $150 \mathrm{~cm}$ [9].

Stocks of humus (SOC) in the main Ukrainian soils also vary widely: humus $100-720 \mathrm{t} / \mathrm{ha}$, SOC $60-420$ t/ha (Tab.2 and Fig.1).

2. Stocks of humus and SOC in Ukrainian soils

\begin{tabular}{|l|c|c|c|}
\hline \multicolumn{1}{|c|}{ Type of soil } & $\begin{array}{c}\text { Humus content in } \\
\text { arable layer,\% }\end{array}$ & $\begin{array}{c}\text { Humus } \\
\text { in profile, } \mathbf{t} / \mathbf{h a}\end{array}$ & $\begin{array}{c}\text { SOC } \\
\text { in profile, } \mathbf{t} / \mathbf{h a}\end{array}$ \\
\hline Chernozems ordinary & $3,5-5,7$ & $200-550$ & $116-319$ \\
\hline Chernozems typical & $2,5-6,0$ & $300-600$ & $174-348$ \\
\hline Chernozems southern & $3,0-3,5$ & $200-250$ & $116-145$ \\
\hline Chernozems podzolized & $2,6-4,5$ & $220-350$ & $128-203$ \\
\hline Chernozem-meadow soils & $3,0-7,2$ & $360-720$ & $209-418$ \\
\hline Gray forest soils & $1,3-3,5$ & $100-230$ & $58-133$ \\
\hline Sod-podzolic soils & $2,0-3,7$ & $150-280$ & $87-162$ \\
\hline
\end{tabular}

According to preliminary expert estimates of NSC ISSAR researchers total SOC stocks in Ukrainian soils are about $7 \mathrm{Gt}$. This compares with $1 / 3$ of SOC in agricultural soils of $\mathrm{EU}$, which are estimated about $18 \mathrm{Gt}$ in 0-30 cm layer [10].

Sources of information on humus and soil organic carbon content. The main sources of information on the content of humus and soil organic carbon on agricultural lands used for the preparation of the National map of Ukraine on soil organic carbon were as follows:

Database "Soil Properties of Ukraine", developed by the NSC ISSAR;

Materials of large-scale soil survey 1957-1961 years;

Materials of agrochemical certification of agricultural lands;

Database of ecological and agro-reclamation state of ameliorated soils, developed by the Institute;

Data of research institutions of various Ministries and Departments and universities;

Data of stationary field experiments listed in State Register of Ukraine.

SOC data for non-agricultural lands (about $18 \mathrm{mln}$.ha) are scattered in dozens of organizations from different Ministries. The collection, analysis and synthesis of ground carbon data for non-agricultural land requires considerable time and cost.

The Institute carries out all-Ukrainian geo-oriented Database "Soil properties of Ukraine", which by 31.01.2017 contained about 2,000 points on the SOC content. Database replenishment is going on by information available in a variety of "soil" organizations of Ukraine (academic institutions, universities, etc.).

Database on the content of organic matter in the soil and its mapping. In NSC ISSAR there is an allUkrainian georeferenced database "Properties of Soils of Ukraine", which, as of 01.02.2017, contained about 2000 points about the content of organic matter in the soil of the country. Due to the participation of Ukraine in the development of the Global Digital Ground Carbon Card for the 0-30 cm layer, the acquisition of the base continues through the collection and synthesis of information available in various "soil" organizations of Ukraine (academic institutions, universities, etc.). First edition of the National Digital Raster SOC Map of Ukraine for $0-30 \mathrm{~cm}$ layer with grid $1 \times 1 \mathrm{~km}$ must be prepared in April 2017 with FAO support.

Loss of humus because of irrational use of land. In Ukraine, since the days of V.V.Dokuchaev there have been conducted numerous researches of organic matter dynamics in soils. They showed that average loss of humus for nearly 130 -year period reached $22 \%$ in forest-steppe, $19.5 \%$ - in the steppe and about $19 \%$ - in Polissya regions of Ukraine. Annual humus loss is $550-600 \mathrm{~kg} / \mathrm{ha}$ and more [11].

The literature also has data on more significant losses, probably due to inaccuracies in determining the geo-orientation of the initial measurements, as well as because of the considerable variegated content of humus, which, as established in special studies [12], is manifested even under absolutely reserved virgin lands. 
According to stationary tests, a long-term plowing and cultivation of soil without adequate fertilizer application leads to significant losses of humus (Table 3) on all analyzed depths - up to $60 \mathrm{~cm}$.

3. Humus content (\%) in virgin (non-turf) and plowed chernozems

\begin{tabular}{|l|l|l|l|l|}
\hline \multirow{2}{*}{$\begin{array}{l}\text { Depth, } \\
\mathrm{cm}\end{array}$} & \multicolumn{2}{|l|}{ Chernozems } & \multicolumn{2}{l|}{} \\
\cline { 2 - 5 } & typical, virgin land & $\begin{array}{l}\text { typical, } \\
\text { arable land }\end{array}$ & $\begin{array}{l}\text { ordinary, } \\
\text { deposit land }\end{array}$ & $\begin{array}{l}\text { ordinary, } \\
\text { arable land }\end{array}$ \\
\hline $0-10$ & 7.76 & 4.58 & 4.61 & 4.25 \\
\hline $10-20$ & 6.08 & 4.55 & 4.35 & 4.20 \\
\hline $20-30$ & 5.05 & 4.51 & 4.28 & 4.12 \\
\hline $30-40$ & 4.79 & 4.29 & 3.74 & 3.48 \\
\hline $40-50$ & 4.05 & 3.85 & 2.80 & 2.61 \\
\hline $50-60$ & 3.82 & 3.60 & 2.65 & 2.49 \\
\hline
\end{tabular}

The highest humus loss occurred in the $60-80$-ies of last century due to increase of sugar beet and maize share in crop rotations. In the following years, level of annual application of organic fertilizers reached 8.4 $\mathrm{t} / \mathrm{ha}$ and $170 \mathrm{~kg} / \mathrm{ha}$ of mineral a.m., therefore equilibrium balances of humus and nutrients were reached. Afterwards, fertilization subsequently reduced and the humus balance became negative. In recent years, application of mineral fertilizers increased to $75 \mathrm{~kg} / \mathrm{ha}$, but there is no perceptible shift for organic fertilizer. NSC ISSAR research as described in [13] shows that humus loss occurs at $43 \%$ of arable land with a speed of up to $620 \mathrm{~kg} / \mathrm{ha}$ per year (SOC loss $360 \mathrm{~kg} / \mathrm{ha}^{*}$ year) depending on rotation structure, tillage and standards of organic fertilizers [11].

Decrease of humus content is mainly due to following factors [13]: high level of plowing (56\% of land area); catastrophic reduction in application of organic fertilizers (last 10 years less than $1.0 \mathrm{t} / \mathrm{ha}$ is applied instead of recommended 8-14); unbalanced use of mineral fertilizers; violation of cropping patterns; monoculture cultivation, reducing area of perennial grasses and legumes; high intensity of tillage.

Measuring, monitoring and reporting on SOC. Basic method of humus measuring is a modified method by I.V.Tyurin, which is standardized in Ukraine and used in all analytical laboratories.

Today, there is no specialized system of SOC monitoring in Ukraine. However, in Ukraine for more than 50 years agrochemical survey of agricultural land is carried out once every five years according to the method developed by NSC ISSAR. For each field 20 soil indicators are defined, including data on averaged humus content.

Only in the ninth round of 2006-2010, $26 \mathrm{mln}$.ha of agricultural lands were surveyed which included taking of about $2.7 \mathrm{mln}$. topsoil samples and preparing more than 450 thousand of agrochemical passports for individual fields [7]. Field passports as legal documents were made for land users and land owners with recommendations how to use and improve soil cover.

SOC management at national level. State of legislative provision of issues on soils protection in Ukraine in recent years has improved with the introduction of the Land Code of Ukraine, Laws of Ukraine "On Land Protection" and "On state control over land use and protection". According to these documents, Government has committed to organize and regulate the use, control and protection of soils.

However, these measures should be considered only the first step. In the nearest future, it is necessary to develop and adopt the laws of Ukraine "On Amendments to Certain Legislative Acts on Improvement of Soil Conservation Mechanisms and Economic Stimulation of Reproduction of Their Fertility"; "On the National Program for the Protection of Soils and the National Program for the Use and Protection of Land"; "On Monitoring of Soils", "On the Establishment of the State Service for the Protection of Land (Soils)" [14, p. 25].

Ukraine as a Party of UNCCD was invited to formulate voluntary targets to achieve Land Degradation Neutrality (LDN) in accordance with specific national circumstances and development priorities.

Therefore, in accordance with p.206 of Outcome Document of UN Conference on Sustainable Development "Rio + 20" and sustainable development goal 15.3 as set out in UN General Assembly documents from 09.25.2015 №70/1, Cabinet of Ministers of Ukraine adopted National Action Plan to Combat 
Land Degradation and Desertification 30.03.2016 p. [15]. It provides activities related to the provision of LDN and SOC stock enhancement.

It is taken into account that according to decision 15/COP 12, one of the three indicators for assessment of the processes of land degradation is "trend in carbon stocks above and below soil," as a metric it is adopted SOC stock in soil.

Unfortunately, funding sources for the implementation of this ambitious Plan are not identified today, therefore the Ministry of Ecology and Natural Resources of Ukraine expressed interest to join to the Land Degradation Neutrality Target Setting Programme (LDN TSP) which has been launched by the Secretariat and the Global Mechanism of the UNCCD with support of several bilateral and multilateral partners to assist Country - Parties to the Convention in implementing decision 3/COP12.

\section{Scientific support of SOC management in Ukrainian chernozems.}

The National Academy of Agrarian Sciences of Ukraine at the expense of state funding carries out with a five-year cycle the research programs on Ukrainian soil conservation and improvement of soil fertility. Currently, NSC ISSAR implements National Research Program for 2016-2020 "Soil resources: Forecast of Development, Sustainable Use and Management".

The studies found the ways of reproduction of humus in current Ukrainian crisis conditions and prepared recommendations for the reduction of row crops share in rotations; use of optimal doses and technologies of mineral and organic-mineral fertilizers; application of technologies of minimum and zero tillage; application of both organic fertilizer plant residues and by-products of crops; growing green manure with subsequent plowing; improved utilization of manure and other organic waste as fertilizer source of SOC accumulation in soil.

NSC ISSAR proposals in Action Plans to increase SOC management capacity on chernozems. International projects and programs:

- Creation of International Network of Centers for chernozems protection with the participation of all interested countries;

- International projects on soil carbon monitoring, dissemination of technologies for SOC improving, on creation and testing of economic incentives for farmers to improve the systems of organic matter in soil;

- Implementation in Ukraine the International Pilot Project for low-cost soil carbon monitoring system on chernozems using spectrometric equipment and technologies of Dutch company SoilCares;

- Organization of international training seminars for studying of SOC monitoring technologies, for example, to study the Ukrainian experience in organizing regular agrochemical survey (certification) of fields;

- $\quad$ Extension of EU project LUCAS on topsoil survey on all European countries, including Ukraine.

National projects with foreign financial and technical support:

- Development of National SOC map in accordance with GSP specifications (carried out with FAO support);

- Creation in Ukraine the National soil-information system; identification of soil information gaps and conducting soil surveys in problem areas;

- Demonstration and dissemination of technologies to improve the humus content in Ukrainian chernozems and reducing of soil degradation;

- $\quad$ SOC loss assessment because of soil sealing in Ukraine;

- Establishment of a all-Ukrainian state system of soil cover monitoring, including SOC indicators;

- Development of theoretical and practical models of economic mechanisms (incentives) to SOC reproduction in agriculture, determine methods of state financial support for SOC reproduction.

\section{Conclusions}

The study shows the role of Ukrainian soils and soil organic carbon management for the sustainability of global food security and agrarian production to climate change. The leading role of Ukraine in the procuring of global food security was identified. It was made a preliminary assessment of the contribution of Ukraine to the global carbon sequestration issue. The extent of organic carbon losses due to inefficient use of land was analyzed. Directions of management of organic carbon reproduction in chernozems of Ukraine are considered for maintenance / increase of its reserves and maintenance of neutral land degradation. 
Proposals for Plans of Actions to increase the capacity of management of organic carbon reproduction in chernozem soils of Ukraine are presented. By managing organic carbon of Ukraine one should focus on increasing the potential of cultivated land for carbon sequestration and mitigating the greenhouse effect. Rational use of land and the prevention of soil degradation can mitigate the effects of climate change and increase the level of food security not only in Ukraine but also in the World. Sequestration of carbon in soils can also increase the agro-industrial sustainability to climate change.

\section{References}

1. The role of soil organic carbon for climate change and food security [Electronic resource]. - Access mode: http://www.fao.org/about/meetings/soil-organic-carbon-symposium/key-messages/ru.

2. New World Atlas of Desertification and Issues of Carbon Sequestration, Organic Carbon Stocks, Nutrient Depletion and Implications for Food Security / P. Zdruli, R. Lal, M. Cherlet, S. Kapur // Carbon Management, Technologies, and Trends in Mediterranean Ecosystems / eds : S. Erşahin, S. Kapur, E. Akça, A. Namlı, H. Erdoğan. The Anthropocene : Politik-Economics-Society-Science, vol. 15. Springer, Cham, 2017. - pp. 13-25. DOI: 10.1007/978-3-319-45035-3_2.

3. Unlocking the Potential of Soil Organic Carbon - Outcome Document of the Global Symposium on Soil Organic Carbon, 21-23 March 2017. - Rome : FAO, 2017. - 36 p.

4. Ukrainian chernozems as a factor in global food security and resilience of agriculture to climate change [Electronic resource] / S. Baliuk, V. Medvedev, A. Kucher, V. Solovey, A. Levin, Y. Kolmaz // Global symposium on soil organic carbon, 21-23 March 2017. - Rome, Italy. - Mode of access: http://www.fao.org/3/a-bs034e.pdf.

5. Kucher A. V. Ecological and economic aspects of development of low-carbon agricultural land use / A. V. Kucher. - Kharkiv : Smuhasta typohrafiya, 2015. - 68 p.

6. National report on the state of the environment in Ukraine in $2014-\mathrm{K}$. : Ministry of Ecology and Natural Resources of Ukraine, Grin D. S. $-2016 .-350$ p.

7. Scientific support of soil resources management in the context of European integration processes : scientific report / A.S. Zaryshnyak, S. A. Baliuk, V. V. Medvedev, R. S. Truskavetskiy, M. M. Miroshnychenko, A. V. Kucher, G. F. Momot. - Kharkiv : Smuhasta typohrafiya, 2016. - 44 p.

8. Kuher A. V. Ukraine and global food security / A. V. Kucher // Modern trends in the development of the world economy: IX International conference, 26 May 2017. T. II. - Kharkiv : KhNADU, 2017. - P. 155-157.

9. National report on soil fertility in Ukraine / ed. S. A. Baliuk, V. V. Medvedev, O. H. Tararika [and others.]. - K., 2010. - $111 \mathrm{c}$.

10. Pan-European SOC stock of agricultural soils [Electronic resource]. European Commission Joint Research Centre, 2013. - Mode of access : http://esdac.jrc.ec.europa.eu/content/pan-european-soc-stockagricultural-soils.

11. Strategy of sustainable use, restoration and management of soil resources in Ukraine / ed. S. A. Baliuk, V. V. Medvedev. - Kyiv : Agricultural Science, 2012. -240 p.

12. Unevenness of soils and accurate farming. Part 2. Results of research / ed. V. V. Medvedev. Kharkiv : City typography, 2009. $-260 \mathrm{c}$.

13. Oldeman L. R. World map of the status of human-induced soil degradation: an explanatory note [Electronic resource] / L. R. Oldeman, R. T. A. Hakkeling, W. G. Sombroek. - Wageningen : International Soil Reference and Information Centre, 1991. - 34 p. - Mode of access: http://www.theeis.com/data/literature/World\%20map\%20of\%20the\%20status\%20of\%20humaninduced\%20soil\%20degradation_1991.pdf.

14. Rational use of soil resources and soil fertility restoration : organizational, economic, ecological and legal aspects : collective monograph / edited by Academician of NAAS S. A. Baliuk, Corresponding Member of AESU A. V. Kucher. - Kharkiv : Smuhasta typohrafiya, 2015. - 432 p.

15. On Approval of the National Action Plan to Combat Land degradation and Desertification [Electronic resource]: Order of the Cabinet of Ministers of Ukraine No. 271-r of March 30, 2016 - Access mode: http://zakon5.rada.gov.ua/laws/show/271-2016-\%D1\%80. 